\title{
Evidence for Renal Kinins as Mediators of Amino Acid-Induced Hyperperfusion and Hyperfiltration in the Rat
}

\author{
Ayad A. Jaffa, "\# Carlos P. Vio," Ricardo H. Silva, " Raymond J. Vavrek," John M. Stewart," Philip F. Rust," \\ and Ronald K. Mayfield* \\ *Departments of Medicine, ${ }^{\ddagger}$ Pharmacology, and "Biometry, Medical University of South Carolina and Veterans Affairs Medical Center, \\ Charleston, South Carolina 29425; ${ }^{\S}$ Department of Physiology, Catholic University, Santiago, Chile; and "Department of Biochemistry, \\ University of Colorado Health Sciences Center, Denver, Colorado 80262
}

\begin{abstract}
This study examined the role of tissue kallikrein and kinins in renal vasodilation produced by infusion of amino acids (AA). In rats fed a $9 \%$ protein diet for 2 wk, intravenous infusion of a $10 \%$ AA solution over $60-90$ min reduced total renal vascular resistance and increased glomerular filtration rate (GFR) by 25-40\% and renal plasma flow (RPF) by 23-30\% from baseline. This was associated with a two- to threefold increase in urinary kinin excretion rate. Acute treatment of rats with aprotinin, a kallikrein inhibitor, resulted in deposition of immunoreactive aprotinin in kallikrein-containing connecting tubule cells and inhibited renal kallikrein activity by $90 \%$. Aprotinin pretreatment abolished the rise in urinary kinins and prevented significant increases in GFR and RPF in response to $A A$. In a second group of rats pretreated with $\mathrm{B}_{2}$ kinin receptor antagonist, [DArg $\mathrm{Hyp}^{3}$, Thi ${ }^{5,8}$ D Phe $\left.^{7}\right]$ bradykinin, AA infusion raised urinary kinins identically as in untreated controls, but GFR and RPF responses were absent. Aprotinin or the kinin antagonist produced no consistent change in renal function in rats that were not infused with AA. AA-induced increases in kinins were not associated with an increase in renal kallikrein activity. Notably, tissue active kallikrein level fell $50 \%$ in AA-infused rats. These studies provide evidence that kinins generated in the kidney participate in mediating renal vasodilation during acute infusion of AA. (J. Clin. Invest. 1992. 89:1460-1468.) Key words: renal function • tissue kallikrein • dietary protein • kallikrein inhibitor • kinin antagonist
\end{abstract}

\section{Introduction}

Several recent studies in animals and humans confirm the earlier findings of Pitts that intravenous infusion of amino acids $(\mathrm{AA})^{1}$ produces a rapid and pronounced rise in glomerular fil-

This work was presented in part at the Annual Meeting of The American Federation for Clinical Research, 28 April-1 May 1989, Washington, DC, and was published in abstract form (Clin. Res. 37:492A).

Address reprint requests to Dr. Ronald K. Mayfield, Department of Medicine, Medical University of South Carolina, 171 Ashley Avenue, Charleston, SC 29425.

Received for publication 22 April 1991 and in revised form $30 \mathrm{De}$ cember 1991

1. Abbreviations used in this paper: $\mathrm{AA}$, amino acids; EDRF, endothelial-derived relaxing factor; GFR, glomerular filtration rate; PAP, peroxidase-antiperoxidase; RPF, renal plasma flow; TRVR, total renal vascular resistance.

The Journal of Clinical Investigation, Inc.

Volume 89, May 1992, 1460-1468 tration rate (GFR) and renal plasma flow (RPF) (1-4). These responses also occur after enteral ingestion of a protein meal $(5$, 6). Micropuncture studies in the rat show that AA infusion lowers resistance of glomerular afferent and efferent arterioles, consequently increasing glomerular capillary plasma flow $(2$, 7). Interest in the renal hemodynamic effects of protein and AA has heightened because of studies demonstrating that lowered glomerular capillary flow and pressure may be one mechanism by which dietary protein restriction slows progression of experimental renal diseases $(8,9)$.

The mediators of AA-induced renal vasodilation are not clearly defined. Several endocrine and paracrine factors have been implicated. Infusion of AA stimulates insulin, glucagon, and growth hormone release. Although glucagon and growth hormone administration can raise GFR and RPF, several studies suggest that individually these hormones do not mediate the actions of AA (10-14). However, some data suggest that insulin, glucagon, and growth hormone in concert may play a role (10).

Amongst paracrine factors, several studies have measured the responses of renal prostaglandins or the effects of inhibiting their production during AA infusion or acute oral protein loading in humans or rats. From these studies, urinary eicosanoid levels do not show consistent responses, and pretreatment with indomethacin attenuates or prevents the rise in GFR and RPF in some but not in other studies (4-6, 11, 15-17). Increases in

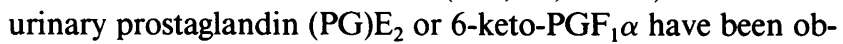
served more consistently after several days of high protein intake (18-21). In addition, glomerular eicosanoid synthesis is increased in rats challenged acutely or chronically with protein $(17,19,22)$.

Sustained high protein intake raises plasma renin activity and renin mRNA levels in the kidney $(18,23,24)$. However, it is difficult to relate the renal vasodilatory effects of protein or AA to increased renin activity. Angiotensin converting enzyme inhibitors can blunt the GFR rise after a protein meal, but these drugs also inhibit kinin degradation and their effects may be due to changes in intrarenal kinin levels (25-28).

We have made recent discoveries that suggest that kallikrein and kinins participate in mediating the renal hemodynamic response to protein $(29,30)$. In normal humans, acute protein ingestion increases renal kinin excretion in parallel with a rise in GFR (29). Continued high protein intake produces a sustained increase in urinary kinins as well as active kallikrein within one to two days (29). In rats, a high protein diet increases renal synthesis of prokallikrein, together with increased excretion of active kallikrein, prokallikrein, and kinins (30). Moreover, treating these rats with aprotinin, a kallikrein inhibitor, lowers GFR and RPF to normal (30). Although these data support the notion that the renal kallikreinkinin system mediates vasodilation induced by protein, such a 
conclusion is tentative. Aprotinin is not a specific inhibitor of kallikrein, and it is a cationic protein. Therefore, its administration may have effects unrelated to inhibiting kallikrein activity or kinin production. In the present study, we employed a recently developed $B_{2}$ kinin receptor antagonist to examine the role of kinins in the acute renal vasodilatory response to AA.

\section{Methods}

Male Sprague-Dawley rats (Charles River Laboratories, Wilmington, MA) weighing 220-240 g were used in all studies. Rats were housed three to four per cage in a temperature and light controlled room, and were fed ad lib. a 9\% protein diet (Teklad Premier Laboratory Diets, Madison, WI) for 10-14 d before acute study. The protein source was casein and the diet was supplemented with methionine to maintain growth.

On the day of study, rats were anesthetized with an intraperitoneal injection of Inactin, $100 \mathrm{mg} / \mathrm{kg}$ body wt (BKY Gulden, Konstanz, FRG). They were immediately placed on a thermo-regulated heating pad and rectal temperature was maintained at $36-37^{\circ} \mathrm{C}$ throughout the experiment. Tracheostomy was performed and the left ureter was cannulated with polyethylene 10 tubing for collection of urine. The left femoral artery was cannulated with polyethylene 50 tubing for blood sampling and direct continuous recording of blood pressure. The tail vein was cannulated with a 27-gauge needle for infusion of solutions. Blood loss associated with surgery ( $1 \%$ body wt) was replaced over 20-30 min with plasma donated from rats also fed $9 \%$ protein. After completion of surgery, rats were allowed to recover for $60 \mathrm{~min}$ before renal function was measured. Saline $(0.9 \%)$ was infused at $2.8 \mathrm{ml} / \mathrm{h}$ during the recovery and baseline measurement periods.

Protocols. To examine the effects of AA on GFR, RPF, and urinary kallikrein and kinins, rats were infused with a $10 \%$ AA mixture (Aminosyn; Abbott Laboratories, Chicago, IL). After two 20-30-min baseline measurement periods, the saline infusion was replaced by the AA solution, infused at the same rate $(2.8 \mathrm{ml} / \mathrm{h})$ for three additional measurement periods of $20-30 \mathrm{~min}$ (280-380 mg AA infused). This protocol was carried out twice, first in conjunction with studying effects of aprotinin $(n=11)$ and subsequently when studying effects of the kinin antagonist $(n=9)$ on renal responses to AA (detailed below). Time control studies were performed by infusing rats with $0.9 \%$ saline $(2.8$ $\mathrm{ml} / \mathrm{h}$ ) for five consecutive periods $(n=7)$. Additional controls were performed by infusing saline for two 30 -min periods followed by $20 \%$ dextrose for three periods $(n=6)$. Dextrose was infused in an amount equivalent to the osmolar load of AA infused to examine if the renal kinin responses were due to osmolality changes.

To examine the effects of a kallikrein inhibitor on the renal vasodilation induced by AA, rats were given an intravenous bolus of aprotinin, 20,000 kallikrein inhibitory units $\mathrm{KIU} / \mathrm{kg}$ body wt, followed by an infusion of $2,000 \mathrm{KIU} / \mathrm{kg}$ per $\min (n=10)$. The bolus was given 30 min before the first baseline measurement period and the infusion continued up to and throughout the baseline and AA challenge periods. The dose of aprotinin was chosen because it inhibited renal kallikrein activity by $90 \%$ and was without effect on systemic blood pressure (31). The effect of this aprotinin dose on renal function was also examined in rats infused with aprotinin for five periods but without AA infused.

To examine the effects of blocking kinin action, AA-infused rats were pretreated with a $\mathbf{B}_{2}$ kinin receptor antagonist (D-Arg-Arg-ProHyp-Gly-Thi-Ser-DPhe-Thi-Arg-TFA). Two doses of antagonist were employed. In one group of rats $(n=8)$ an intravenous bolus of 10 $\mu \mathrm{g} / \mathrm{kg}$, given at the beginning of the first baseline period, was followed by continuous infusion of $0.5 \mu \mathrm{g} / \mathrm{kg}$ per min throughout baseline and AA infusion periods. In a second group $(n=5)$ a bolus of $20 \mu \mathrm{g} / \mathrm{kg}$ was followed by infusion of $1.0 \mu \mathrm{g} / \mathrm{kg}$ per min throughout. The effect of the latter dose on kinin-induced hypotension was tested in rats pretreated with converting enzyme inhibitor. This dose inhibited by $30-50 \%$ the effect of an intravenous bradykinin bolus titrated to reduce mean arterial pressure $15-20 \mathrm{mmHg}$. The effect of $1.0 \mu \mathrm{g} / \mathrm{kg}$ per min kinin antag- onist on renal function was also examined in rats infused with antagonist for five periods but without AA infused.

At the end of all studies, kidneys were excised, perfused free of blood with iced $0.9 \%$ saline, and stored at $-20^{\circ} \mathrm{C}$ for subsequent measurements of total protein, active and prokallikrein, and kallikrein-like esterase activity.

Clearance studies. GFR and RPF were measured by the renal clearance of ${ }^{51} \mathrm{Cr}$-EDTA (New England Nuclear, Boston, MA) and ${ }^{125} \mathrm{I}$ Orthoiodohippuran (Amersham Corp., Arlington Heights, IL), respectively. An intravenous bolus of $2 \mu \mathrm{Ci} / 100 \mathrm{~g}$ body wt ${ }^{51} \mathrm{Cr}$-EDTA and $0.5 \mu \mathrm{Ci} / 100 \mathrm{~g}^{125} \mathrm{I}$-Hippuran in $150 \mu \mathrm{l}$ saline was followed by infusion of $10 \mu \mathrm{Ci} / \mathrm{h}{ }^{51} \mathrm{Cr}$-EDTA and $2.5 \mu \mathrm{Ci} / \mathrm{h}{ }^{125} \mathrm{I}$-Hippuran. These isotopes were mixed in the saline or AA solution such that total fluid infused remained at $2.8 \mathrm{ml} / \mathrm{h}$. Infusion of isotopes was begun $60 \mathrm{~min}$ before clearance measurements. Urine was collected from the left ureter over 20-30 min into preweighed polypropylene tubes, kept on ice to preserve kinins. Arterial blood $(200 \mu \mathrm{l})$ was drawn at the midpoint of each urine collection for measurement of hematocrit, plasma protein concentration, and radioactivities of ${ }^{51} \mathrm{Cr}$ and ${ }^{125} \mathrm{I}$. Blood drawn was replaced with rat plasma. Radioactivities in urine and plasma were counted in a dual channel gamma counter and clearances expressed as milliliters per minute per kidney. Hippuran extraction was determined from concentrations in peripheral arterial blood and renal venous blood drawn at the end of each study. RPF was corrected for the extraction ratio. In preliminary studies, we determined that aprotinin and the kinin antagonist did not alter Hippuran extraction. Total renal vascular resistance (TRVR) was calculated by the formula: TRVR = mean blood pressure ( $\mathrm{mmHg}$ ) divided by renal blood flow. Renal blood flow equals RPF/(1-hematocrit).

Preparation of kidney homogenate. Excised kidneys were perfused via the renal hilus by a hand-held syringe with $10 \mathrm{ml}$ of ice-cold $0.9 \%$ saline and then immediately stored at $-20^{\circ} \mathrm{C}$. Subsequently, kidneys were thawed, minced, and homogenized in $5 \mathrm{ml} P B S(0.14 \mathrm{M} \mathrm{NaCl}$ in $\left.0.01 \mathrm{M} \mathrm{Na}_{2} \mathrm{HPO}_{4}-\mathrm{NaH}_{2} \mathrm{PO}_{4}, \mathrm{pH} 7.4\right)$ with 15 strokes of a Teflon homogenizer (Wheaton Instruments, Millville, NJ). Sodium deoxycholate was added to the homogenate ( $0.5 \%$ final concentration), followed by incubation at $4^{\circ} \mathrm{C}$ for $60 \mathrm{~min}$. The homogenate was centrifuged $\left(27,000 \mathrm{~g}\right.$ at $4^{\circ} \mathrm{C}$ for $\left.45 \mathrm{~min}\right)$ and the resultant supernatant was centrifugally filtered through Sephadex G 25 (Pharmacia Inc., Piscataway, NJ) to remove salts and detergent. Filtered supernatant was used for measurement of kallikrein, kallikrein-like esterase activity, and total protein.

Assays. Active and prokallikrein were measured by a monoclonal antibody radioimmunoassay which has been described in detail (32). The antibody recognizes only active tissue kallikrein (33). Prokallikrein was determined by assaying active kallikrein in each sample before and after trypsin treatment, which converts all prokallikrein to active enzyme, and subtracting the pretreatment concentration from the total after trypsin. Kallikrein-like esterase activity was measured according to the method of Beavan et al., using ${ }^{3} \mathrm{H}$-tosyl-L-arginine methyl ester substrate (34). To measure urinary kinins, urine was collected directly from the ureter into iced tubes. 1 vol of urine, free of blood as determined by Labstix (Miles Laboratories Inc., Elkhart, IN), was placed in $4 \mathrm{vol}$ of absolute ethanol. The mixture was centrifuged at $5,000 \mathrm{~g}$ and the supernatant recovered and dried under air. The dried residue was reconstituted in kinin assay buffer for direct radioimmunoassay (35). Protein concentration in kidney homogenates and plasma was determined by the method of Lowry et al. (36).

Immunocytochemistry. Immunocytochemical co-localization of kallikrein and aprotinin was performed in kidneys of seven rats infused with aprotinin and AA, as described above, to determine if aprotinin localized to kallikrein-containing connecting tubule cells (37). At the end of the infusion, the kidney was removed and immediately sliced into 2-mm sections, which were fixed in Bouin's solution for 24-48 h. Sections were then embedded in paraffin (Paraplast-Plus; Brunswick Labs, St. Louis, MO) or plastic (Methacrylate; Ladd Research Industries, Burlington, VT). For Paraplast-Plus embedding, tissues were dehydrated in a graded series of ethanol solutions followed by $n$-butanol 

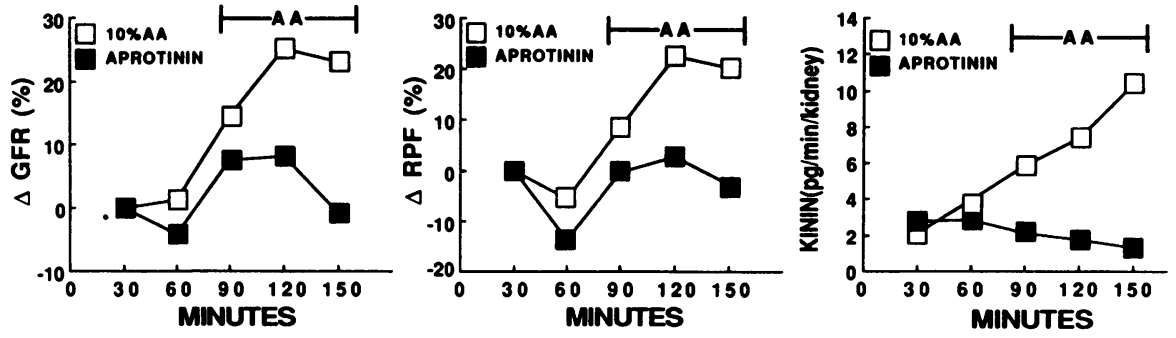

Figure 1. GFR, RPF, and urinary kinin excretion rate during baseline (30 and 60 min) and amino acid infusion (90 to 150 $\mathrm{min})$. Values at each point were measured over the preceding 30 -min interval. Control rats (open squares) and aprotinin-treated rats (closed squares) received $380 \mathrm{mg}$ of amino acid mixture ( $10 \%$ solution) over 90 min. Aprotinin-treated rats received a bolus of aprotinin $(20,000 \mathrm{KIU} / \mathrm{kg})$ followed by an infusion of $2,000 \mathrm{KIU} / \mathrm{kg}$ per min, started 30 min before the first baseline period. Significant increases in GFR, RPF, and urinary kinins in control rats $(P<0.001$ for all AA periods) were prevented by aprotinin treatment.

and then Paraplast-Plus; serial consecutive sections $5 \mu \mathrm{m}$ thick (semithick sections) were then cut and mounted on glass slides. Methacrylate embedding was done as previously described (38). Tissues were dehydrated in a graded series of ethanol solutions followed by pure acetone. Infiltration was done with 1:1 mixture of acetone and methacrylate (an 8:2 mixture of butyl-methacrylate and methyl-methacrylate) for $1 \mathrm{~h}$ at room temperature. Tissues were then transferred to glass vials containing an 8:2 mixture of butyl-methacrylate to methyl-methacrylate with $1 \mathrm{mg} / \mathrm{ml}$ of Irgacure 651 (Ladd Research Industries) as a catalyst. Complete polymerization was obtained under a cold ultraviolet lamp after $12-24 \mathrm{~h}$ of exposure. Serial sections of $1 \mu \mathrm{m}$ (thin sections) were cut on an ultramicrotome and mounted on glass slides.

The immunostaining procedure employed was the unlabeled antibody method of Sternberger and Joseph, as previously modified to describe the cellular localization of kallikrein in the rat nephron (38). The following supplies were obtained commercially: goat antiserum against rabbit IgG, normal rabbit serum, normal goat serum, peroxidase-antiperoxidase (PAP) complex of rabbit origin (SternbergerMeyer, Jarrestville, MD). Semi-thick (Paraplast) or thin (methacrylate) sections were subjected to immunoperoxidase staining. All antisera and PAP complexes were diluted in $0.05 \mathrm{M}$ Tris-phosphate (pH 7.6) containing $0.7 \% \lambda$-carageenan, and $0.5 \%$ Triton $X-100$. The antiserum dilutions used were as follows: kallikrein, 1:10,000; aprotinin, 1:4,000. Immunostaining was accomplished by incubating the tissue mounted on glass slides for $18-24 \mathrm{~h}$ in glass staining jars containing different primary antisera at $22^{\circ} \mathrm{C}$. Slides were then incubated with second antibody (goat antiserum against rabbit IgG; $1: 20$ ) for $30 \mathrm{~min}$, followed by PAP complex (1:150) for $30 \mathrm{~min}$, and then incubated with a solution containing $0.2 \% 3,3^{\prime}$-diamino-benzidine tetrahydrochloride and $0.01 \%$ $\mathrm{H}_{2} \mathrm{O}_{2}$ in $0.5 \mathrm{M}$ Tris-phosphate ( $\mathrm{pH} \mathrm{7.6)}$ ) for $15 \mathrm{~min}$. Between incubations slides were extensively washed with buffer. After staining, slides were dehydrated, cleared with xylene, and cover-slipped. The tissue sections were counterstained with hematoxylin, studied in a Nikon Optiphot microscope and photographed with a Nikon Microflex UFXIIA photographic system (Nippon Kogagu K.K., Tokyo, Japan). The specificity of the immunostaining was demonstrated by prior absorption of antisera with pure aprotinin or kallikrein (37).
Statistical analysis. Data are expressed as mean \pm SEM and were analyzed by analysis of variance for repeated measurements. Differences were considered significant if $P<0.05$. In analyzing data from renal function studies, the Scheffe's contrast was employed to take advantage of preassigned baseline and AA-infusion periods. This test guards against type I error due to multiple analyses.

\section{Results}

Effects of amino acids on renal function and kinins. Fig. 1 and Table I show the effects of AA infusion on left kidney GFR, RPF, and renal kinin excretion. Expressed as percent change from the initial baseline value at $30 \mathrm{~min}$, GFR increased $25 \%$ during AA in control rats (Fig. 1). From an average baseline level of $1.51 \pm 0.09 \mathrm{ml} / \mathrm{min}$, GFR increased during AA to $1.89 \pm 0.10 \mathrm{ml} / \mathrm{min}$ at $90-120 \mathrm{~min}(P<0.001$, Table I). RPF increased $23 \%$, from an average baseline of $6.06 \pm 0.47 \mathrm{ml} / \mathrm{min}$ to $7.53 \pm 0.57 \mathrm{ml} / \mathrm{min}$ at $90-120 \mathrm{~min}(P<0.001)$. Filtration fraction was unchanged $(0.25 \pm 0.01$ vs. $0.26 \pm 0.01$, baseline vs. AA, respectively). As shown in Table II, TRVR fell during AA infusion. Renal vasodilation was accompanied by more than a threefold rise in excretion rate of kinins (Fig. 1). Urinary kinins increased from an average baseline excretion rate of $2.75 \pm 0.43$ $\mathrm{pg} / \mathrm{min}$ per kidney to $10.1 \pm 1.71$ at $150 \min (P<0.001)$.

Saline infusion at the same volume rate as AA produced no change in GFR or RPF (Table III). Moreover, saline infusion produced no significant change in renal kinin excretion $(3.95 \pm 1.20$ vs. $5.77 \pm 1.75 \mathrm{pg} / \mathrm{min}$ per kidney, $0-30 \mathrm{~min}$ vs. 120-150 min, respectively). In addition, a 90-min infusion of $20 \%$ dextrose, at a volume rate and osmolar load equal to the AA, produced no significant change in GFR, RPF, or urinary kinin excretion (GFR, $1.43 \pm 0.08$ vs. $1.29 \pm 0.03 \mathrm{ml} / \mathrm{min}$; RPF, $6.30 \pm 0.58$ vs. $4.68 \pm 0.25 \mathrm{ml} / \mathrm{min}$; kinins, $5.42 \pm 0.92$ vs.

Table I. Renal Function in Control and Aprotinin-treated Rats Infused with Amino Acids

\begin{tabular}{|c|c|c|c|c|c|}
\hline \multirow[b]{2}{*}{ Minutes } & \multicolumn{2}{|c|}{ Baseline } & \multicolumn{3}{|c|}{ Amino acids } \\
\hline & $0-30$ & $30-60$ & $60-90$ & $90-120$ & $120-150$ \\
\hline \multicolumn{6}{|c|}{ GFR $(\mathrm{ml} / \mathrm{min})$} \\
\hline Control & $1.51 \pm 0.08$ & $1.53 \pm 0.11$ & $1.73 \pm 0.09^{*}$ & $1.89 \pm 0.10^{*}$ & $1.86 \pm 0.12^{*}$ \\
\hline Aprotinin & $1.47 \pm 0.06$ & $1.41 \pm 0.08$ & $1.58 \pm 0.07$ & $1.59 \pm 0.09$ & $1.46 \pm 0.12$ \\
\hline \multicolumn{6}{|c|}{$\operatorname{RPF}(\mathrm{ml} / \mathrm{min})$} \\
\hline Control & $6.14 \pm 0.40$ & $5.80 \pm 0.52$ & $6.67 \pm 0.50^{*}$ & $7.53 \pm 0.57^{*}$ & $7.37 \pm 0.67^{*}$ \\
\hline Aprotinin & $5.73 \pm 0.30$ & $4.94 \pm 0.30^{\ddagger}$ & $5.69 \pm 0.25$ & $5.89 \pm 0.34$ & $5.58 \pm 0.52$ \\
\hline
\end{tabular}

${ }^{*} P<0.001$ vs. baseline period. ${ }^{\ddagger} P<0.05$ vs. $0-30$-min period. 
Table II. Effects of Infusing Amino Acids in Control or Aprotinin-treated Rats

\begin{tabular}{|c|c|c|c|c|c|}
\hline \multirow[b]{2}{*}{ Minutes } & \multicolumn{2}{|c|}{ Baseline } & \multicolumn{3}{|c|}{ Amino acids } \\
\hline & $0-30$ & $30-60$ & $60-90$ & $90-120$ & $120-150$ \\
\hline \multicolumn{6}{|c|}{ Mean arterial pressure $(\mathrm{mmHg})$} \\
\hline Control & $103 \pm 2$ & $108 \pm 2$ & $110 \pm 2$ & $109 \pm 2$ & $105 \pm 2$ \\
\hline Aprotinin & $104 \pm 2$ & $108 \pm 3$ & $107 \pm 2$ & $109 \pm 3$ & $106 \pm 3$ \\
\hline \multicolumn{6}{|l|}{ Plasma protein $(g / d l)$} \\
\hline Control & $5.8 \pm 0.2$ & $5.7 \pm 0.2$ & $5.6 \pm 0.2$ & $5.5 \pm 0.2$ & $5.7 \pm 0.2$ \\
\hline Aprotinin & $5.9 \pm 0.2$ & $5.8 \pm 0.3$ & $5.8 \pm 0.3$ & $4.7 \pm 0.3$ & $6.0 \pm 0.4$ \\
\hline \multicolumn{6}{|l|}{ Hematocrit (vol \%) } \\
\hline Control & $43.1 \pm 0.6$ & $42.4 \pm 0.6$ & $42.0 \pm 0.5$ & $41.5 \pm 0.6$ & $41.4 \pm 0.6$ \\
\hline Aprotinin & $45.0 \pm 0.8$ & $44.3 \pm 0.9$ & $43.4 \pm 1.0$ & $43.1 \pm 1.0$ & $43.0 \pm 1.1$ \\
\hline \multicolumn{6}{|c|}{ Urine volume $(\mu \mathrm{l} / \mathrm{min})$} \\
\hline Control & $21.4 \pm 3.2$ & $27.6 \pm 5.1$ & $32.0 \pm 6.1$ & $30.3 \pm 4.6$ & $31.3 \pm 5.8$ \\
\hline Aprotinin & $20.4 \pm 4.6$ & $20.8 \pm 4.4$ & $26.1 \pm 4.6$ & $27.9 \pm 5.3$ & $20.4 \pm 4.6$ \\
\hline \multicolumn{6}{|c|}{ TRVR $(\mathrm{mmHg} / \mathrm{ml}$ per min) } \\
\hline Control & $12.3 \pm 0.9$ & $14.5 \pm 1.3$ & $12.7 \pm 1.1^{*}$ & $11.3 \pm 1.1^{*}$ & $11.1 \pm 0.8^{*}$ \\
\hline Aprotinin & $12.8 \pm 0.7$ & $15.8 \pm 1.3$ & $13.6 \pm 0.7$ & $13.5 \pm 0.7$ & $14.7 \pm 1.4$ \\
\hline
\end{tabular}

${ }^{*} P<0.003$ vs. baseline period.

$4.62 \pm 1.14 \mathrm{pg} / \mathrm{min}$ per kidney, 0-30 min baseline vs. $120-150$ min dextrose, respectively).

Effect of aprotinin on amino acid-induced changes. In rats treated with aprotinin and subsequently infused with AA, baseline GFR was unchanged (Fig. 1 and Table I). However, RPF fell slightly between the first and second baseline periods $(5.73 \pm 0.30$ vs. $4.94 \pm 0.30$, Table I). Because this was statistically significant, the $30-60$ min baseline RPF was used for analysis of subsequent changes during AA. The isolated drop in RPF at 30-60 min appeared not to be a consistent effect of aprotinin, because rats infused for $150 \mathrm{~min}$ with aprotinin, but without AA, showed no change in RPF or GFR (Table III).

In aprotinin-treated rats, AA infusion did not produce a significant change in GFR or RPF (Fig. 1 and Table I). Aprotinin also abolished the rise in urinary kinins and fall in TRVR during AA (Fig. 1 and Table II). Mean arterial pressure, plasma protein concentration, hematocrit, and urine volume were not altered during the baseline period by aprotinin, compared to control rats, and these parameters were unchanged from baseline during AA infusion in either group (Table II). Renal kallikrein-like esterase activity was markedly inhibited in aprotinin-treated rats compared to uninfused controls ( $236 \pm 28$ vs. $2324 \pm 174$ milliesterase $\mathrm{U} / \mathrm{g}$ protein, $P<0.001$ ).

Immunocytochemical localization of aprotinin. Immunostaining of aprotinin and kallikrein was carried out in 20 consecutive serial sections of kidney from each of seven rats treated with aprotinin. Fig. $2, A-F$, shows two consecutive serial sections from three kidneys. Intense kallikrein immunoreactivity was seen in connecting tubule cells that lie adjacent to the afferent arteriole (photomicrographs $A, C$, and $E$ ). Aprotinin immunoreactivity was observed in the same portion of the nephron $(B, D$, and $F)$. In the $1-\mu \mathrm{m}$ methacrylate sections, identical connecting tubule cells can be seen that contain both kallikrein and aprotinin (photomicrographs $E$ and $F$ ). Aprotinin or kallikrein was not seen in glomeruli, afferent or efferent arterioles, or macula densa. However, aprotinin staining was seen in

Table III. Renal Function in Rats Infused with Saline, Aprotinin, or Kinin Antagonist (1.0 $\mu \mathrm{g} / \mathrm{kg}$ per min)

\begin{tabular}{|c|c|c|c|c|c|}
\hline Minutes & $0-30$ & $30-60$ & $60-90$ & $90-120$ & $120-150$ \\
\hline \multicolumn{6}{|l|}{ Saline } \\
\hline GFR $(\mathrm{ml} / \mathrm{min})$ & $1.36 \pm 0.06$ & $1.40 \pm 0.05$ & $1.38 \pm 0.05$ & $1.39 \pm 0.08$ & $1.48 \pm 0.06$ \\
\hline $\operatorname{RPF}(\mathrm{ml} / \mathrm{min})$ & $5.01 \pm 0.27$ & $4.70 \pm 0.22$ & $4.85 \pm 0.22$ & $5.04 \pm 0.43$ & $5.24 \pm 0.31$ \\
\hline \multicolumn{6}{|l|}{ Aprotinin } \\
\hline GFR $(m l / m i n)$ & $1.11 \pm 0.06$ & $1.38 \pm 0.10$ & $1.29 \pm 0.05$ & $1.25 \pm 0.06$ & $1.35 \pm 0.07$ \\
\hline $\mathrm{RPF}(\mathrm{ml} / \mathrm{min})$ & $4.39 \pm 0.36$ & $5.19 \pm 0.47$ & $4.80 \pm 0.20$ & $4.47 \pm 0.16$ & $4.81 \pm 0.18$ \\
\hline Minutes & $0-20$ & $20-40$ & $40-60$ & $60-80$ & $80-100$ \\
\hline \multicolumn{6}{|l|}{ Kinin antagonist } \\
\hline GFR $(\mathrm{ml} / \mathrm{min})$ & $1.05 \pm 0.08$ & $1.25 \pm 0.15$ & $1.16 \pm 0.08$ & $1.25 \pm 0.04$ & $1.26 \pm 0.09$ \\
\hline $\operatorname{RPF}(\mathrm{ml} / \mathrm{min})$ & $3.94 \pm 0.12$ & $4.73 \pm 0.86$ & $4.10 \pm 0.13$ & $4.48 \pm 0.21$ & $4.42 \pm 0.30$ \\
\hline
\end{tabular}



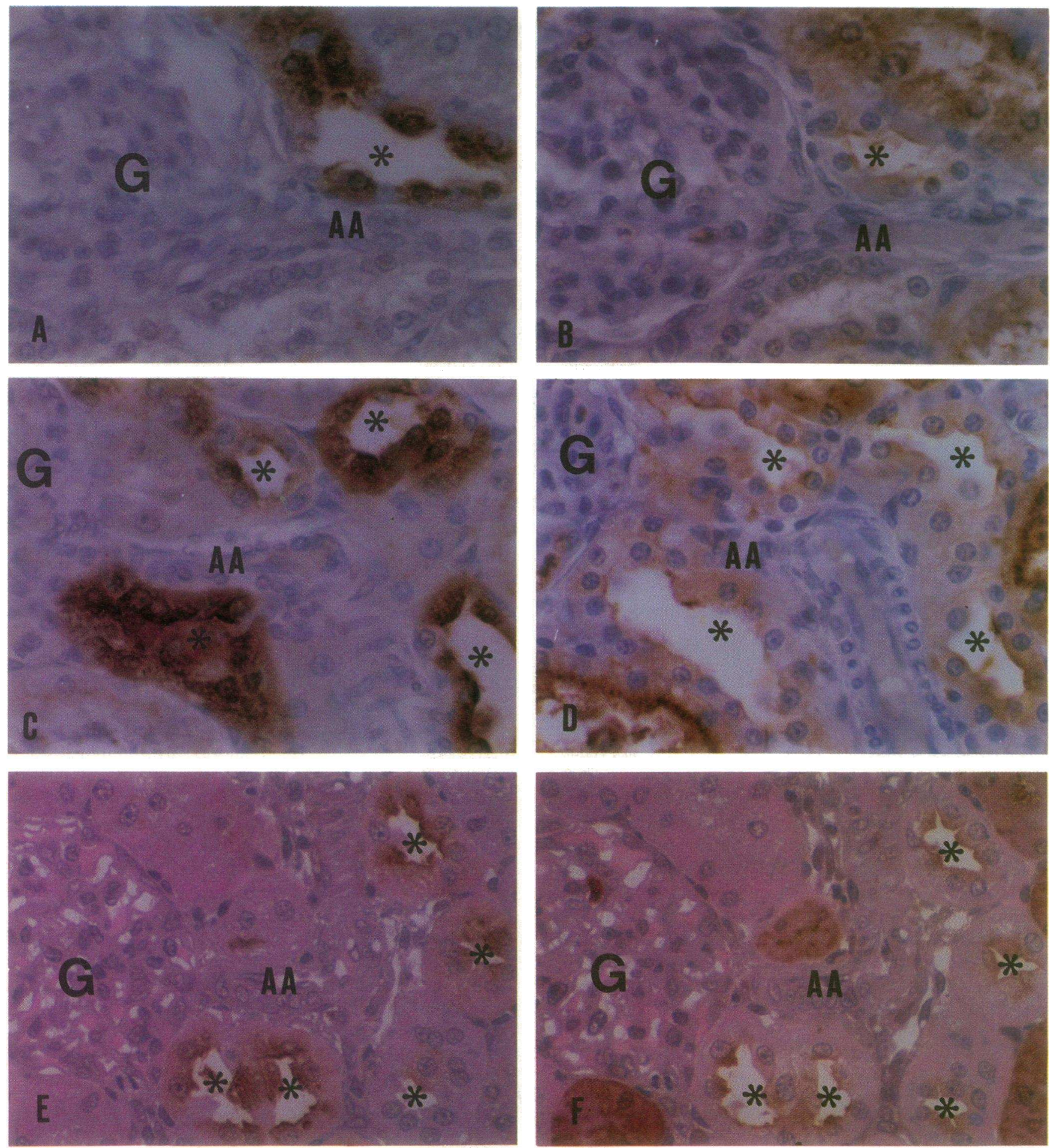

Figure 2. Immunocytochemical localization of kallikrein $(A, C, E)$ and aprotinin $(B, D, F)$ in adjacent serial sections. Sections $A-D$ are 5- $\mu \mathrm{m}$ thick paraffin sections, and $E-F$ are 1- $\mu \mathrm{m}$ thick methacrylate sections. Connecting tubules (*) can be seen adjacent to the afferent arteriole $(A A)$ leading to a glomerulus $(G)$. In thick sections, the same connecting tubules that contains kallikrein positive cells $(A$ and $C)$ also show positive staining for aprotinin in the adjacent serial section $(B$ and $D)$. In adjacent thin sections $(E$ and $F)$, the same cells can be identified that contain kallikrein and aprotinin immunoreactivity. Some aprotinin staining is seen in proximal tubules where filtered aprotinin was reabsorbed.

proximal tubule segments, where reabsorption of filtered aprotinin occurs.

Effects of kinin receptor antagonist on renal function. Fig. 3 and Table IV show the effects of $\mathbf{a}_{\mathbf{2}}$ kinin receptor antagonist on baseline and AA-induced changes in renal function. In untreated control rats in this study, AA infusion increased left kidney GFR by $40 \%$, from an average baseline level of $1.47 \pm 0.06$ to $1.98 \pm 0.13 \mathrm{ml} / \mathrm{min}$ at $60-80 \mathrm{~min}(P<0.001$, Table IV). RPF increased $30 \%$, from an average baseline of $5.59 \pm 0.27$ to $7.46 \pm 0.48 \mathrm{ml} / \mathrm{min}(P<0.001)$. As before, filtration fraction did not change $(0.25 \pm 0.01$ vs. $0.27 \pm 0.01$, baseline vs. AA, respectively). Similar to the first study, AA-induced 

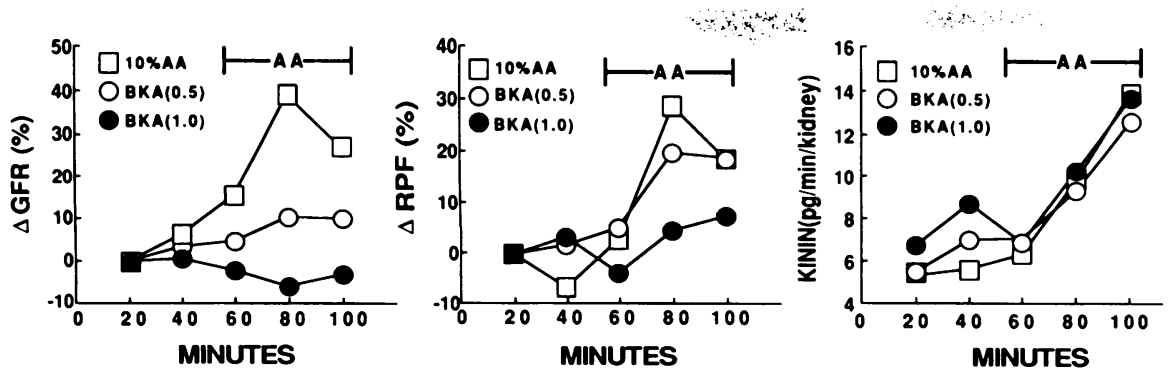

Figure 3. GFR, RPF, and urinary kinin excretion rate during baseline (20 and 40 $\mathrm{min})$ and amino acid infusion (60-100 $\mathrm{min}$ ). Values at each point were measured over the preceding 20 -min period. Control rats (open squares) and kinin antagonisttreated rats (open circles and solid circles) received $280 \mathrm{mg}$ of amino acid mixture (10\% solution) over $60 \mathrm{~min}$. The kinin antagonist was injected as a bolus of $10 \mu \mathrm{g} / \mathrm{kg}$ (open circles) or $20 \mu \mathrm{g} / \mathrm{kg}$ (solid circles) at

the beginning of the first baseline period, followed by the continuous infusion of 0.5 or $1.0 \mu \mathrm{g} / \mathrm{kg}$ per min, respectively. GFR and RPF increased significantly in controls $(P<0.001$ for all AA periods) but not in antagonist-treated rats. Kinin excretion was unaltered by the antagonist and increased twofold $(P<0.001)$ in all groups.

increases in GFR and RPF were associated with a marked rise in urinary kinins (Fig. 3). Urinary kinin excretion increased from an average baseline rate of $5.49 \pm 2.16 \mathrm{pg} / \mathrm{min}$ per kidney to $13.9 \pm 6.96$ at $100 \mathrm{~min}(P<0.001$, Fig. 3$)$.

In rats treated with the lower dose of kinin antagonist $(0.5$ $\mu \mathrm{g} / \mathrm{kg}$ per min) GFR and RPF did not increase significantly during AA (Fig. 3 and Table IV). However, there was a tendency for RPF to rise, and TRVR did fall significantly (Table $\mathrm{V})$. The higher dose of kinin antagonist ( $1 \mu \mathrm{g} / \mathrm{kg}$ per min) completely blocked GFR, RPF, and TRVR responses to AA. Although these functional responses were blocked by the kinin antagonist, the rise in urinary kinins was unaltered by either dose of antagonist and was nearly identical in magnitude in antagonist-treated and control groups (Fig. 3). Infusion of the higher dose of antagonist produced no change in GFR or RPF over five periods in rats not given AA (Table III).

Mean arterial pressure, plasma protein concentration, and hematocrit were not different during baseline in antagonisttreated rats compared to control rats, and these parameters did not change during AA infusion in either group (Table V). Although baseline urine volume tended to be lower in rats treated with the high dose of antagonist, the difference was not statistically significant. Moreover, during AA infusion, urine volume did not change in any of the groups.

Renal and urinary kallikrein. To study mechanisms for increased renal kinin generation in response to AA, we measured renal kallikrein level, activity, and excretion rate. By radioimmunoassay, renal active kallikrein in AA-infused rats was reduced at least $50 \%$, compared to levels in either uninfused or saline-infused rats (Fig. 4). Kallikrein-like esterase activity was similarly reduced $(1,222 \pm 178,2,324 \pm 174$, and $2,256 \pm 312$ milliesterase $\mathrm{U} / \mathrm{g}$ protein in AA-infused, uninfused, and salineinfused rats, respectively). Prokallikrein levels (RIA) were not significantly different between these three groups $(10.8 \pm 0.9$, 12.7 $\pm 0.6,11.4 \pm 0.9, \mathrm{ng} / \mathrm{mg}$ protein).

Despite the fall in.renal tissue active kallikrein, urinary excretion rates of active and prokallikrein were not changed by AA infusion (active: $88 \pm 8$ vs. $82 \pm 17 \mathrm{ng} / \mathrm{min}$, prokallikrein: $32 \pm 4$ vs. $37 \pm 4 \mathrm{ng} / \mathrm{min}$, baseline vs. AA, respectively). Urinary kallikrein-like esterase activity was similarly unchanged $(1.64 \pm 0.17$ vs. $1.81 \pm 0.26$ milliesterase/min, baseline vs. AA, respectively).

\section{Discussion}

The present studies show that AA-induced increases in renal perfusion and filtration are associated with a marked rise in urinary kinins; that administration of a kallikrein inhibitor prevents the rise in urinary kinins and attenuates the increases in GFR and RPF in response to AA; and finally, that a kinin receptor antagonist abolishes GFR and RPF responses to AA despite increased kinin production. Collectively these findings strongly suggest that kinins are involved in mediating renal hemodynamic responses to AA and may provide the clearest demonstration thus far for a role of kinins as mediators of physiologic hemodynamic events in the kidney.

Although the function of the kallikrein-kinin system in renal hemodynamic homeostasis is not clearly defined, a number of studies implicate its participation. Kinins infused into the renal artery in high doses increase glomerular plasma flow by reducing resistance of afferent and efferent arterioles, but GFR does not increase significantly because the ultrafiltration

Table IV. Renal Function in Control or Kinin Antagonist-treated (0.5 or $1.0 \mu \mathrm{g} / \mathrm{kg}$ per min) Rats Infused with Amino Acids

\begin{tabular}{|c|c|c|c|c|c|}
\hline \multirow[b]{2}{*}{ Minutes } & \multicolumn{2}{|c|}{ Baseline } & \multicolumn{3}{|c|}{ Amino acids } \\
\hline & $0-20$ & $20-40$ & $40-60$ & $60-80$ & $80-100$ \\
\hline \multicolumn{6}{|l|}{ GFR $(\mathrm{ml} / \mathrm{min})$} \\
\hline Control & $1.42 \pm 0.07$ & $1.51 \pm 0.06$ & $1.64 \pm 0.06^{*}$ & $1.98 \pm 0.13^{*}$ & $1.80 \pm 0.09^{*}$ \\
\hline$(0.5 \mu \mathrm{g} / \mathrm{kg}$ per $\min )$ & $1.71 \pm 0.16$ & $1.77 \pm 0.11$ & $1.79 \pm 0.04$ & $1.89 \pm 0.04$ & $1.88 \pm 0.06$ \\
\hline$(1.0 \mu \mathrm{g} / \mathrm{kg}$ per $\min )$ & $1.53 \pm 0.11$ & $1.54 \pm 0.06$ & $1.50 \pm 0.09$ & $1.44 \pm 0.13$ & $1.48 \pm 0.12$ \\
\hline \multicolumn{6}{|l|}{$\mathrm{RPF}(\mathrm{ml} / \mathrm{min})$} \\
\hline Control & $5.78 \pm 0.32$ & $5.39 \pm 0.25$ & $5.93 \pm 0.28^{*}$ & $7.46 \pm 0.48^{*}$ & $6.87 \pm 0.38^{*}$ \\
\hline$(0.5 \mu \mathrm{g} / \mathrm{kg}$ per min $)$ & $6.04 \pm 0.67$ & $6.15 \pm 0.44$ & $6.35 \pm 0.24$ & $7.25 \pm 0.19$ & $7.18 \pm 0.21$ \\
\hline$(1.0 \mu \mathrm{g} / \mathrm{kg}$ per $\min )$ & $5.45 \pm 0.55$ & $5.62 \pm 0.28$ & $5.23 \pm 0.28$ & $5.69 \pm 0.64$ & $5.77 \pm 0.81$ \\
\hline
\end{tabular}

${ }^{*} P<0.001$ vs. baseline period. 
Table V. Effects of Infusing per Amino Acids (Control) or Amino Acids and Kinin Antagonist (0.5 or $1.0 \mu \mathrm{g} / \mathrm{kg} \mathrm{per}$ min)

\begin{tabular}{|c|c|c|c|c|c|}
\hline \multirow[b]{2}{*}{ Minutes } & \multicolumn{2}{|c|}{ Baseline } & \multicolumn{3}{|c|}{ Amino acids } \\
\hline & $0-20$ & $20-40$ & $40-60$ & $60-80$ & $80-100$ \\
\hline \multicolumn{6}{|c|}{ Mean arterial pressure $(\mathrm{mmHg})$} \\
\hline Control & $100 \pm 2$ & $103 \pm 2$ & $105 \pm 2$ & $104 \pm 2$ & $102 \pm 3$ \\
\hline$(0.5 \mu \mathrm{g} / \mathrm{kg}$ per $\mathrm{min})$ & $103 \pm 4$ & $105 \pm 4$ & $107 \pm 3$ & $106 \pm 3$ & $100 \pm 3$ \\
\hline$(1.0 \mu \mathrm{g} / \mathrm{kg}$ per $\min )$ & $102 \pm 4$ & $103 \pm 4$ & $103 \pm 4$ & $101 \pm 4$ & $98 \pm 4$ \\
\hline \multicolumn{6}{|l|}{ Plasma protein $(g / d l)$} \\
\hline Control & $6.5 \pm 0.5$ & $6.7 \pm 0.4$ & $6.0 \pm 0.3$ & $6.0 \pm 0.4$ & $6.1 \pm 0.4$ \\
\hline$(0.5 \mu \mathrm{g} / \mathrm{kg}$ per $\min )$ & $6.6 \pm 0.3$ & $6.3 \pm 0.4$ & $6.3 \pm 0.4$ & $6.3 \pm 0.2$ & $6.6 \pm 0.2$ \\
\hline$(1.0 \mu \mathrm{g} / \mathrm{kg}$ per $\min )$ & $5.9 \pm 0.3$ & $5.4 \pm 0.4$ & $6.7 \pm 0.7$ & $5.9 \pm 0.3$ & $5.3 \pm 0.1$ \\
\hline \multicolumn{6}{|l|}{ Hematocrit (vol \%) } \\
\hline Control & $48.4 \pm 0.9$ & $48.0 \pm 1.0$ & $46.4 \pm 1.1$ & $46.3 \pm 0.9$ & $46.1 \pm 1.0$ \\
\hline$(0.5 \mu \mathrm{g} / \mathrm{kg}$ per $\min )$ & $47.4 \pm 0.6$ & $46.1 \pm 0.7$ & $46.1 \pm 0.7$ & $45.6 \pm 1.1$ & $45.3 \pm 0.8$ \\
\hline$(1.0 \mu \mathrm{g} / \mathrm{kg}$ per $\min )$ & $46.4 \pm 1.4$ & $45.2 \pm 1.7$ & $45.0 \pm 1.4$ & $43.6 \pm 1.4$ & $45.0 \pm 1.9$ \\
\hline \multicolumn{6}{|l|}{ Urine volume $(\mu \mathrm{l} / \mathrm{min})$} \\
\hline Control & $22.3 \pm 6.0$ & $27.6 \pm 5.9$ & $22.1 \pm 4.0$ & $17.9 \pm 2.4$ & $16.2 \pm 2.1$ \\
\hline$(0.5 \mu \mathrm{g} / \mathrm{kg}$ per $\min )$ & $29.4 \pm 4.2$ & $30.6 \pm 3.5$ & $26.5 \pm 3.5$ & $22.4 \pm 2.3$ & $24.3 \pm 4.5$ \\
\hline$(1.0 \mu \mathrm{g} / \mathrm{kg}$ per $\min )$ & $13.6 \pm 4.8$ & $11.4 \pm 3.2$ & $9.3 \pm 2.5$ & $7.1 \pm 2.1$ & $7.9 \pm 3.3$ \\
\hline \multicolumn{6}{|c|}{ TRVR (mmHg/ml per min) } \\
\hline Control & $11.1 \pm 0.6$ & $12.5 \pm 0.7$ & $12.1 \pm 0.6$ & $9.6 \pm 0.7$ & $10.4 \pm 0.8$ \\
\hline$(0.5 \mu \mathrm{g} / \mathrm{kg}$ per $\min )$ & $11.9 \pm 1.1$ & $11.9 \pm 0.8$ & $11.6 \pm 0.6^{*}$ & $9.9 \pm 0.4^{*}$ & $9.6 \pm 0.4^{*}$ \\
\hline$(1.0 \mu \mathrm{g} / \mathrm{kg}$ per $\mathrm{min})$ & $13.1 \pm 1.5$ & $12.7 \pm 6.0$ & $13.8 \pm 1.0$ & $13.3 \pm 1.9$ & $12.3 \pm 1.8$ \\
\hline
\end{tabular}

${ }^{*} P<0.01$ vs. baseline period.

coefficient falls (39). Infusion of lower doses of kinin into the isolated perfused kidney raises both GFR and RPF (40). The disparity in GFR and RPF responses to high dose kinin is also seen with other potent vasodilators, such as $\mathrm{PGE}_{2}$, which raise RPF but not GRF when infused (39). Although the renal vasodilatory effect of exogenously infused kinins are blocked by a kinin antagonist, it is difficult to conclude from infusing kinins

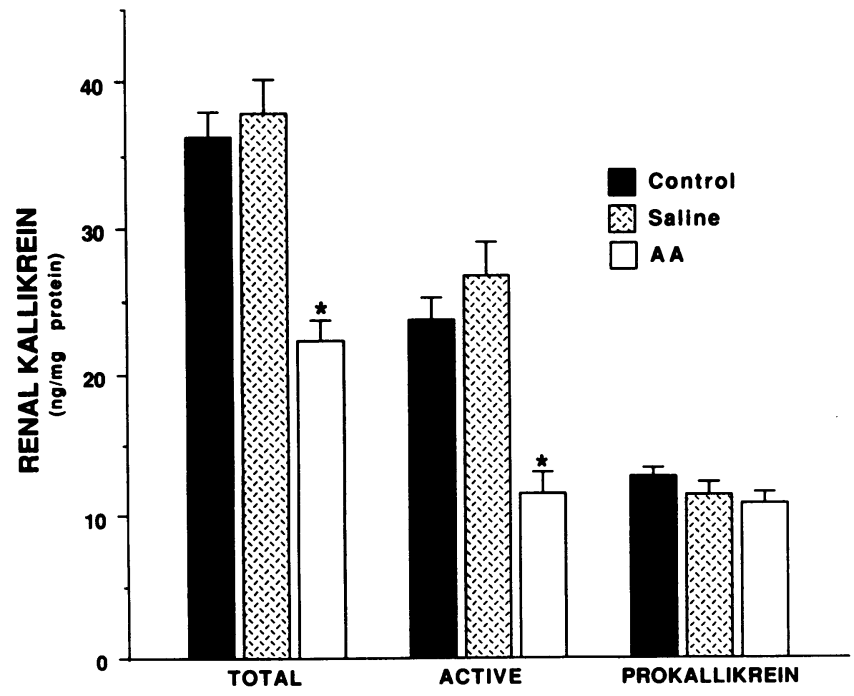

Figure 4. Renal tissue kallikrein levels in uninfused control (solid bar), saline-infused (stippled bar), and amino acid-infused (open bar) rats. Tissue levels were measured at the end of the infusion period. Amino acid infusion produced a $50 \%$ reduction in active kallikrein. how endogenously generated kinins regulate glomerular function (41).

The same kinin antagonist we employed has been used by others to study the role of endogenous kinins in renal hemodynamic regulation. Infusion of the antagonist into normal rats reduced RPF but not GFR $(42,43)$. A similar effect on RPF has been observed in sodium depleted dogs $(44,45)$. However, when GFR, RPF, and kinin levels were elevated by administering kininase inhibitors, the kinin antagonist reduced GFR as well as RPF in normal and deoxycorticosterone-treated rats $(46,47)$. These observations may be relevant to our findings that AA-induced increases in GFR and RPF, associated with increased kinin production, were blocked by the kinin antagonist, whereas the antagonist had no effect on baseline function in rats fed $9 \%$ protein. We previously reported that $9 \%$ proteinfed rats have low basal kinin excretion (30). Therefore, ours and previous data suggest that the effect of the kinin antagonist on renal function depends on the renal kinin levels.

Fernandez-Repollet et al. reported that protein-restricted rats have elevated renal vascular resistance and administration of captopril, a kininase II inhibitor, reduces the resistance (23). Given our findings, it is quite plausible that the fall in renal vascular resistance produced by captopril in protein-restricted rats is due to increased renal kinin levels rather than reduced angiotensin II. This notion is supported by our observation that renal kininase activity is increased in $9 \%$ protein-fed rats and falls with AA infusion (unpublished data).

We were surprised to find that active renal kallikrein levels fell following AA, while urinary excretion of active kallikrein did not change. We previously showed that rats chronically fed a high $(50 \%)$ protein diet manifest increased renal synthesis and excretion of kallikrein, together with increased urinary 
kinin excretion (30). In other studies we were not able to detect any changes in kallikrein synthesis or release into the venous circulation which would explain the fall in tissue level following AA (unpublished data). Collectively, our data suggest that reduced kinin degradation contributes to increased renal kinins following acute AA or chronic dietary protein challenge, and during chronic high protein intake an increase in kallikrein activity may also contribute. Nonetheless, the present study shows that the increase in kinin excretion during AA infusion is dependent on kallikrein, or another kininogenase that is inhibited by aprotinin. When aprotinin was given in a dose that inhibited renal kallikrein activity by $90 \%$, kinins did not increase in response to AA, and neither GFR nor RPF increased.

We cannot exclude the possibilities that aprotinin blocked the responses to AA by inhibiting another kininogenase or by a nonspecific renal or extrarenal effect. However, aprotinin did not alter function in rats that were not infused with AA. Moreover, immunocytochemical co-localization showed that aprotinin rapidly accumulated in kallikrein-containing cells of the connecting tubule. This suggests that kallikrein was inhibited at its cellular site of release by the acute aprotinin infusion. Thus, given all of our findings, it seems most likely that aprotinin inhibited hemodynamic responses to AA by inhibiting renal kallikrein, the predominate kininogenase in kidney.

The exact mechanisms by which kallikrein in the connecting tubule could regulate glomerular function are unclear, but several recent findings provide anatomical and functional frameworks for such a role. First, immunocytochemical studies in rat and human kidney demonstrate in more than $80 \%$ of nephrons that the connecting tubule containing kallikrein passes within $3 \mu \mathrm{m}$ of the afferent arteriole $(48,49)$. Low molecular weight kininogen substrate is contained in principal cells, which are interspersed with connecting tubule cells in this nephron segment (50). Secondly, kallikrein trafficks to the basolateral membrane of connecting tubule cells (37). As an ectoenzyme on the basolateral cell membrane, or upon release into the interstitial space, kallikrein could generate kinins near the afferent arteriole (51). Third, it has been demonstrated that kinins added to the antilumenal side of isolated perfused rat afferent arterioles results in reduced resistance (52). Finally, $B_{2}$ kinin receptors have been identified in isolated glomerular membranes, suggesting that other sites within the glomerulus may also be functionally responsive to kinins (53).

Our data indicate that kinins are acting through a $B_{2}$ kinin receptor to reduce renal vascular resistance following $A A$. We cannot conclude whether their actions are direct or via generation of secondary vasoactive products. Kinins can induce prostacyclin and $\mathrm{PGE}_{2}$ production by isolated rat afferent arterioles (54). A recent preliminary report suggests that bradykinin also stimulates release of endothelial-derived relaxing factor (EDRF) from glomerular endothelial cells co-cultured with mesangial cells (55). Two other studies have found that $\mathrm{L}-N^{\mathrm{G}}$ monomethyl arginine, an inhibitor of EDRF synthesis, partially or completely blocks GFR and RPF responses to AA infusion in rats $(56,57)$. Therefore, eicosanoids or EDRF may be downstream mediators or modulators of kinin's actions on the glomerulus.

In summary, the present findings, together with our previous observations in rats and humans $(29,30)$, support the concept that amino acids as well as dietary protein alter the activity of the renal kallikrein-kinin system, and these changes participate in mediating renal hemodynamic responses to amino acids and protein.

\section{Acknowledgments}

We thank Kim Sutton and Michael Bigelow for technical assistance and Ms. Pam Beasley for assistance in preparing the manuscript. Aprotinin was generously provided by Bayer AG, Wuppertal, FRG.

This work was supported by a Merit Review Grant from the Department of Veterans Affairs. Dr. Jaffa is the recipient of a Research and Development Award from the American Diabetes Association. Dr. Vio is supported in Chile by Fondo Nacional de Desarrollo Cientifico y Tecnologico.

\section{References}

1. Pitts, R. F. 1944. The effects of infusing glycine and of varying the dietary protein intake on renal hemodynamics in the dog. Am. J. Physiol. 142:355-365.

2. Meyer, T. W., I. Ichikawa, R. Zatz, and B. M. Brenner. 1983. The renal hemodynamic response to amino acid infusion in the rat. Trans. Assoc. Am. Physicians. 96:76-83.

3. Premen, A. J. 1989. Nature of the renal hemodynamic action of amino acids in dogs. Am. J. Physiol. 256:F516-F523.

4. Ruilope, L. M., J. Rodicio, R. G. Robles, J. Sancho, B. Miranda, J. P. Granger, and J. C. Romero. 1987. Influence of low sodium diet on the renal response to amino acid infusions. Kidney Int. 31:992-999.

5. Hostetter, T. H. 1986. Human responses to a meat meal. Am. J. Physiol. 250:F613-F618.

6. Krishna, G. G., G. Newell, E. Miller, P. Heeger, R. Smith, M. Polansky, S. Kapoov, and R. Hoeldtke. 1988. Protein-induced glomerular hyperfiltration: role of hormonal factors. Kidney Int. 33:578-583.

7. Baylis, C. 1988. Effect of amino acid infusion as an index of renal vasodilatory capacity in pregnant rats. Am. J. Physiol. 254:F650-F656.

8. Hostetter, T. H., T. W. Meyer, H. G. Rennke, and B. M. Brenner. 1986. Chronic effects of dietary protein in the rat with intact and reduced renal mass. Kidney Int. 30:509-517.

9. Zatz, R., T. W. Meyer, S. Anderson, and H. G. Rennke. 1985. Predominance of hemodynamic rather than metabolic factors in the pathogenesis of diabetic glomerulopathy. Proc. Natl. Acad. Sci. USA. 82:5963-5967.

10. Castellino, P., W. Hunt, and R. A. DeFronzo. 1987. Regulation of renal hemodynamics by plasma amino acid and hormone concentrations. Kidney Int. 32(Suppl. 22):S15-S20.

11. DeFronzo, R. A., M. Goldberg, and Z. Agus. 1976. The effect of glucose and insulin on renal electrolyte transport. J. Clin. Invest. 58:83-90.

12. Premen, A. J., J. E. Hall, and M. J. Smith. 1985. Postprandial regulation of renal hemodynamics: role of pancreatic glucagon. Am. J. Physiol. 248:F656F662.

13. Hirschberg, R., and J. D. Kopple. 1987. Role of growth hormone in the amino acid-induced acute rise in renal function in man. Kidney Int. 32:382-387.

14. Premen, A. J. 1988. Potential mechanisms mediating postprandial renal hyperemia and hyperfiltration. FASEB (Fed. Am. Soc. Exp. Biol.) J. 2:131-137.

15. Hirschberg, R. R., R. D. Zipser, L. A. Slomowitz, and J. D. Kopple. 1988. Glucagon and prostaglandins are mediators of amino acid-induced rise in renal hemodynamics. Kidney Int. 33:1147-1155.

16. Herrara, J., B. Rodriguez-Iturbe, G. Parra, J. Coello, R. Garcia, J. ColinaChourio, and A. Sinaiko. 1988. Urinary prostaglandin E and kallikrein activity in glomerular hyperfiltration induced by a meat meal in man. Clin. Nephrol. 30:151-157.

17. Levine, M. M., M. A. Kirschenbaum, A. Chaudari, M. W. Wong, and N. S. Bricker. 1986. Effect of protein on glomerular filtration rate and prostanoid synthesis in normal and uremic rats. Am. J. Physiol. 251:F635-F641.

18. Paller, M. S., and T. H. Hostetter. 1986. Dietary protein increases plasma renin and reduces pressor reactivity to angiotensin II. Am. J. Physiol. 251:F34F39.

19. Benigni, A., C. Zoja, A. Remuzzi, S. Orisio, A. Piccinelli, and G. Remuzzi. 1986. Role of renal prostaglandins in normal and nephrotic rats with diet-induced hyperfiltration. J. Lab. Clin. Med. 108:230-240.

20. Rosenberg, M. E., J. E. Swanson, B. L. Thomas, and T. H. Hostetter. 1987. Glomerular and hormonal responses to dietary protein intake in human renal disease. Am. J. Physiol. 253:F1083-F1090.

21. Daniels, B. S., and T. H. Hostetter. 1990. Effects of dietary protein intake on vasoactive hormones. Am. J. Physiol. 258:R1095-R1100.

22. Don, B. R., S. Blake, F. N. Hutchison, G. A. Kaysen, and M. Schambelan. 1989. Dietary protein intake modulates glomerular eicosanoid production in the rat. Am. J. Physiol. 256:F711-F718.

23. Fernandez-Repollet, E., E. Tapia, and M. Martinez-Maldonado. 1987. 
Effect of angiotensin-converting enzyme inhibition on altered renal hemodynamics induced by low protein diet in the rat. J. Clin. Invest. 80:1045-1049.

24. Rosenberg, M. E., D. Chnielewski, and T. H. Hostetter. 1990. Effect of dietary protein on rat renin and angiotensin gene expression. J. Clin. Invest. 85:1144-1149.

25. Eisenhauer, T., J. Talartschik, and F. Scheler. 1986. Angiotensin converting enzyme inhibition by captopril reduces amino acid-induced increase in glomerular filtration rate. J. Hypertens. 4:S258-S260.

26. Corman, B., and J.-B. Michel. 1988. Interdependence of food intake and angiotensin converting enzyme inhibition on kidney function. $J$. Hypertens. 6:S65-S68.

27. Chagnac, A., U. Gafter, D. Zevin, Y. Hirsch, I. Markovitz, and J. Levi. 1989. Enalapril attenuates glomerular hyperfiltration following a meat meal. Nephron. 51:466-469.

28. McCaa, R. E. 1979. Studies in vivo with angiotensin I converting enzyme (Kininase II) inhibitors. Fed. Proc. 38:2783-2787.

29. Bolin, P., A. A. Jaffa, P. F. Rust, and R. K. Mayfield. 1989. Effects of protein and amino acid ingestion on renal kallikrein and kinin excretion in humans. Am. J. Physiol. 257:F718-F723.

30. Jaffa, A. A., J. N. Harvey, S. E. Sutherland, H. S. Margolius, and R. K. Mayfield. 1989. Renal kallikrein responses to dietary protein: a possible mediator of hyperfiltration. Kidney Int. 36:1003-1010.

31. Seto, S., V. Kher, A. G. Scicli, W. H. Beierwaltes, and O. A. Carretero. 1983. The effect of aprotinin (a serine protease inhibitor) on renal function and renin release. Hypertension (Dallas). 5:893-899.

32. Jaffa, A. A., D. H. Miller, G. S. Bailey, J. Chao, H. S. Margolius, and R. K Mayfield. 1987. Abnormal regulation of renal kallikrein in experimental diabetes. Effects of insulin on prokallikrein synthesis and activation. J. Clin. Invest. 80:1651-1659.

33. Ando, T., J. Chao, L. Chao, and H. S. Margolius. 1986. An improved method for the measurement of rat tissue kallikrein using a monoclonal antibody which recognizes only active kallikrein. Adv. Exp. Med. Biol. 198B:515-522.

34. Beavan, V. H., J. V. Pierce, and J. J. Pisano. 1971. A sensitive isotopic procedure for the assay of esterase activity: measurement of human urinary kallikrein. Clin. Chim. Acta. 32:67-73.

35. Shimamato, K., T. Ando, T. Nakao, S. Tanaka, M. Sakuma, and M. Miyahara. 1978. A sensitive radioimmunoassay method for urinary kinins in man. J. Lab. Clin. Med. 91:721-728.

36. Lowry, O. H., N. J. Rosebrough, A. L. Farr, and R. J. Randall. 1951. Protein measurement with the Folin phenol reagent. J. Biol. Chem. 193:265-275.

37. Vio, C. P., and C. D. Figueroa. 1985. Subcellular localization of renal kallikrein by ultrastructural immunocytochemistry. Kidney Int. 28:36-42.

38. Vio, C. P., J. P. Roa, R. Silva, and C. A. Powers. 1990. Localization of immunoreactive glandular kallikrein in lactotrophs of the rat anterior pituitary. Neuroendocrinology. 51:10-14.

39. Baylis, C., W. M. Deen, B. D. Myers, and B. M. Brenner. 1976. Effects of some vasodilator drugs on transcapillary fluid exchange in renal cortex. Am. $J$. Physiol. 230:1148-1158.

40. Maier, M., Z. Zhegu, and B. R. Binder. 1986. Hemodynamics of the isolated perfused rat kidney in the absence and presence of kallikrein substrate. Adv. Exp. Med. Biol. 198:173-180.
41. Gardes, J., T. Baussant, P. Corvol, J. Menard, and F. Alenc-Gelas. 1990. Effect of bradykinins and kininogens in isolated rat kidney vasoconstricted by angiotension II. Am. J. Physiol. 258:F1273-F1281.

42. Madeddu, P., N. Glorioso, A. Soro, P. Manunta, C. Troffa, G. Tonolo, M. Melis, and A. Pazzola. 1990. Effect of a kinin antagonist on renal function and hemodynamics during alterations in sodium balance in conscious normotensive rats. Clin. Sci. (Lond.). 78:165-168.

43. Seino, M., K. Abe, N. Nushiro, K. Omata, Y. Kasai, and K. Yoshinaga. 1988. Effects of a competitive antagonist of bradykinin on blood pressure and renal blood flow in anesthetized rats. J. Hypertens. 6:867-871.

44. Beierwaltes, W. H., O. A. Carretero, and A. G. Scicli. 1988. Renal hemodynamics in response to a kinin analogue antagonist. Am. J. Physiol. 255:F408F414.

45. Zimmerman, B. G., P. C. Raich, R. J. Vavrek, and J. M. Stewart. 1990. Bradykinin contribution to renal blood flow effect of angiotensin converting enzyme inhibitor in conscious sodium-restricted dog. Circ. Res. 66:242-248.

46. Nakagawa, M., J. M. Stewart, R. J. Vavrek, and A. Nasjletti. 1990. Effects of a kinin antagonist on renal function in rats. Am. J. Physiol. 258:F643-F648.

47. Fitzgibbon, W. R., A. A. Jaffa, R. K. Mayfield, and D. W. Ploth. 1990. Role of kinins in the renal response to converting enzyme inhibition. Clin. Res. 38:428A. (Abstr.)

48. Barajas, L., K. Powers, O. A. Carretero, A. G. Scicli, and T. Inagami. 1986. Immunocytochemical localization of renin and kallikrein in the rat renal cortex. Kidney Int. 29:965-970.

49. Vio, C. P., C. D. Figueroa, and I. Caorsi. 1988. Anatomical relationship between kallikrein-containing tubules and the juxtaglomerular apparatus in the human kidney. Am. J. Hypertens. 1:269-271.

50. Figueroa, C. D., A. G. MacIver, J. C. Mackenzie, and K. D. Bhoola. 1988. Localization of immunoreactive kininogen and tissue kallikrein in the human nephron. Histochemistry. 89:437-442.

51. Chao, J., and H. S. Margolius. 1979. Studies on rat renal cortical cell kallikrein. II. Identification of kallikrein as an ectoenzyme. Biochim. Biophys. Acta. 570:330-340.

52. Edwards, R. M. 1985. Response of isolated renal arterioles to acetylcholine, dopamine and bradykinin. Am. J. Physiol. 248:F183-F189.

53. Emond, C., J. L. Bascands, G. Cabos-Bontot, C. Pecker, and J. P. Girolami. 1989. Effects of changes in sodium or water intake on glomerular $\mathrm{B}_{2}$-kininbinding sites. Am. J. Physiol. F353-F358.

54. Hura, C. E., and R. T. Kunau. 1988. Angiotensin II-stimulated prostaglandin production by canine afferent arterioles. Am. J. Physiol. 254:F734-F738.

55. Marsden, P. A., T. A. Brock, and B. J. Ballerman. 1989. Glomerular endothelial cells respond to calcium-mobilizing agonists with release to endothelium-derived relaxing factor. Clin. Res. 37:496A. (Abstr.)

56. King, A. J., J. L. Troy, S. J. Downes, S. Anderson, and B. M. Brenner. 1990. Effects of $N$-monomethyl-L-arginine (L-NMMA) on basal renal hemodynamics and the response to amino acid (AA) infusion. Kidney Int. 37:371. (Abstr.)

57. Tolins, J. P., and L. Raij. 1991. Effects of amino acid infusion on renal hemodynamics: role of endothelium-derived relaxing factor. Hypertension (Dallas). 17:1045-1051. 